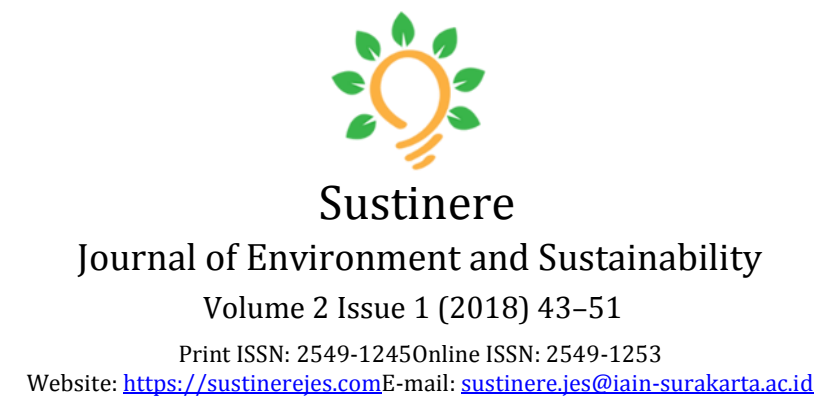

SHORT COMMUNICATION

\title{
An approach to identify soil types by using hydraulic conductivity values
}

\author{
Maritha Nilam Kusuma1,2, Wahyono Hadi ${ }^{1}$, Budisantoso Wirjodirdjo ${ }^{3}$ and \\ Yulfiah $^{2}$ \\ ${ }^{1}$ Department of Environmental Engineering, Institut Teknologi Sepuluh Nopember, Indonesia \\ ${ }^{2}$ Department of Environmental Engineering, Institut Teknologi Adhi Tama Surbaya, Indonesia \\ ${ }^{3}$ Department of Industrial Engineering, Institut Teknologi Sepuluh Nopember, Indonesia \\ Article history: \\ Received 13 February 2018 | Accepted 06 April 2018 | Available online 25 May 2018
}

\begin{abstract}
Water treatment in Indonesia still uses coagulant to reduce the contaminant. Therefore, an infiltration gallery is required as the pre-treatment before conventional water treatment conducted. Infiltration gallery is a natural technology for absorbing or filtrating the contaminant. The hydraulic conductivity plays the main role in soil filtration. There are many types of soil with different hydraulic conductivities. In infiltration gallery method it is important to identify the hydraulic conductivity value as the preliminary analysis because it is the important indicator to show the ability of soil to flow the water from one side to other sides when filtrating the contaminant. The slower the conductivity is, the better the quality of the water will be. The method used in this study was the Constant head Permeameter. The result of this study shows that the same type of soil type has different hydraulic conductivities.
\end{abstract}

Keywords: Hydraulic conductivity; soil; water treatment

\section{Introduction}

The infiltration gallery method utilizes a natural filtration system on the soil which then collects water into a hollow pipe and sends it into the collecting wells. Infiltration gallery is divided into two: one is mounted below while another is paralleled to the river (Asare \& Bosque-Hamilton, 2004). Infiltration gallery is installed in the vadose zone. It is a zone that is not saturated by water, so it contains soil which can be bypassed by water easily. The vadose zone is divided into two based on the diameter of the sand and the ratio between sand and clay. Riverbank and infiltration gallery can reduce organic substances, pharmaceutical, microbiological parameters and toxins from algae (Jekel \& Heinzmann, 2003). The application of infiltration gallery in the southern city of Nassau New York is capable of processing $770 \mathrm{~kg} /$ day of nitrate, $3800 \mathrm{~kg} /$ day of chloride and $24800 \mathrm{~kg} /$ day of TSS (Sulam \& Ku, 1977). Moreover, it was able to reduce Schistosoma mansoni and e.coli in tap drinking water for the population of St Lucia West India (Unrau, 1975; Davis, 1979). Biological parameters treated by infiltration gallery at Goviefe-Agodome showed that $94 \%$ coli could be filtered by influents of $388 / 100 \mathrm{ml}$ to $24 / 100 \mathrm{~mL}$ (Barbiero et al. 2008). 
According to WHO, the amount which is allowed is 0-10/100 mL (Barbiero et al. 2008). Fecal coliform decreased by $91 \%$ (Barbiero et al. 2008). Australia installed a 0.5 meter to 10-meter infiltration gallery in the water-unsaturated zone (Rummler et al., 2015). The use of cheap and simple infiltration gallery can increase the filtration rate, hydraulic (Martin \& Dillion, 2002). The harmful components on the water can be removed due to evaporation in the infiltration gallery (Martin \& Dillion, 2002). Riverbed can decrease the turbidity parameter by $96 \%$, Total Kjeldahl Nitrogen (TKN) is $>99 \%$ (Hutchinson et al., 2011). Infiltration gallery is able to reduce nitrite of various soil types and water depths. However, it is less effective in lowering nitrate and phosphorus (B.C. Ministry of Environment, 2014). The working principle of infiltration gallery and riverbank is the same as the slow sand filter (Kusuma et al., 2018b). Both water treatments are affected by the quality of raw water, the filtration rate, the addition of media, and the soil type (Henzler et al., 2014; Hoffman \& Gunkel, 2014; Jones, 2008; Paterson, 2011; Bekele et al., 2013). For those reasons, we need a preliminary study to identify the type of soil with reference to the value of hydraulic conductivity. The goal of the research is to gain preassessment on application infiltration gallery as an alternative solution for water pretreatment.

\section{Literature review}

Infiltration gallery is a technology for processing water by natural soil mechanism processing. This tool consists of the perforated pipe that is covered by the gravel for collecting water from infiltration (Bekele et al., 2015; Barbiero et al., 2008; Jones, 2008; Jurel et al., 1995). Water processing mechanism in the soil includes adsorption, filtration, degradation and recovery, or they so-called purification (Bekele et al., 2015). Infiltration gallery is able to remove physical and chemical parameters. Infiltration gallery is able to reduce $68 \%$ of TSS, nitric and phosphate $28 \%$ and $28.5 \%$ respectively (Assare and Bosque-Hamilton, 2004).

Filtering process in the soil depends on porosity, water velocity, pore size distribution, pore homogeneity, adsorption, filtration, sedimentation, and the movement of bacteria in it (Henzler et al., 2014; Hoffman \& Gunkel, 2014; Jones, 2008; Paterson, 2011; Bekele et al., 2013)

Basically, the infiltration gallery and riverbank has the same principle as the slow sand filter (Kusuma et al., 2018b). Both water treatments are affected by the quality of raw water, filtration rate, media, and soil type (Henzler et al., 2014; Hoffman \& Gunkel, 2014; Jones, 2008; Paterson, 2011; Bekele et al., 2013). The difference is that while on the SSF the media used has been determined (homogeneous), in the infiltration gallery and river bank, the soil particle size distribution is heterogeneous. Therefore, soil that is passed by water using an infiltration gallery has a heterogeneous structure. Previous research indicated the ability of the soil to absorb pollutants and their applications (Barbiero et al., 2008; Jones, 2008; Dalai \& Ramakarjha, 2014; Aqualinc, 2014; Rummler et al., 2015; Tagar et al., 2016; Blavier et al., 2014). Some modelling has been investigated earlier, for example, the model of pollutant distribution caused by infiltration from the river bank in Berlin, Germany (Henzler, 2014). Physical modelling has two types of infiltration gallery with gravel media and Atlantis leach system to determine hydraulic speed (Bekele et al., 2013). While Atlantis leach system is a filtration system using a thick modular 
polypropylene material, filtration modelling aims to determine the penetration power of water to the soil containing bentonite slurry (Yoon \& Mochtar, 2015). Therefore, the selection of these factors can be used as a starting point in system engineering to get the best performance behaviour pattern of infiltration gallery. This approach is applied to the behaviour patterns of performance system to get TSS with the good quality and total coli which is close to zero so that IPAM can save coagulant. This method analyzes the behavioural patterns of infiltration gallery with the dynamic system approach. Factors affecting the success of infiltration gallery are the distribution of soil particles, specific gravity, porosity, saturation degree, hydraulic conductivity and the soil type. Below is the formula to calculate the conductivity:

$$
\begin{gathered}
C v=\frac{0,197\left(H t^{2}\right)}{t 50} \\
C v=\frac{0,848\left(H t^{2}\right)}{\sqrt{t 90}} \\
K h t_{50}=C v \times \partial \times M v
\end{gathered}
$$

\section{Material and methods}

The tool which was used in this study was Selbi Tube with the height of $60 \mathrm{~cm}$. This tool helps the researcher to collect the undisturbed soil. Soil without disturbance from the natural structure is needed because we want to know its ability to flow the water which is called as permeability. Some locations of soil which was taken as the sample are Surabaya, Sidoarjo, Lumajang, Mojokerto, Bangkalan, and Gresik. It was collected from January to March 2016. Our next research was to do conductivity analysis using the Constant Head Permeameter method as ASTM D 2434-68SNI 03 - 6871 2002. The sample would be taken from the northern city of East Java, to answer a key question about the local soil type that is able to remove the TSS and coli to be standard drinking water. Sampling was conducted using Selbi tubes to get undisturbed soil. to get unchanged soil, located in the same area. The treatment was conducted to keep the undisturbed soil by inserting the tube into the soil. Extrusion tools were used in the consolidation tool to obtain the hydraulic conductivity value. Soil sampling is showed in Figure 1. 


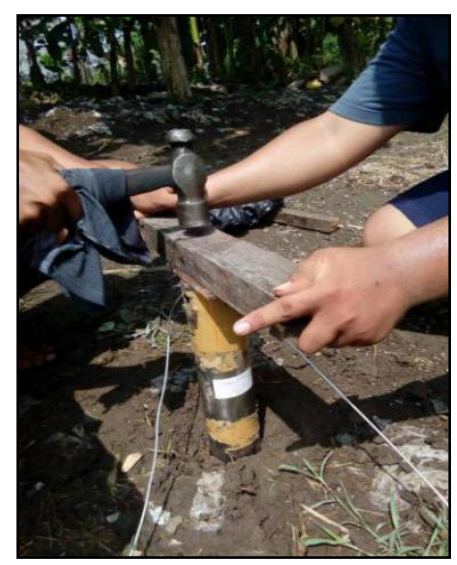

(a)

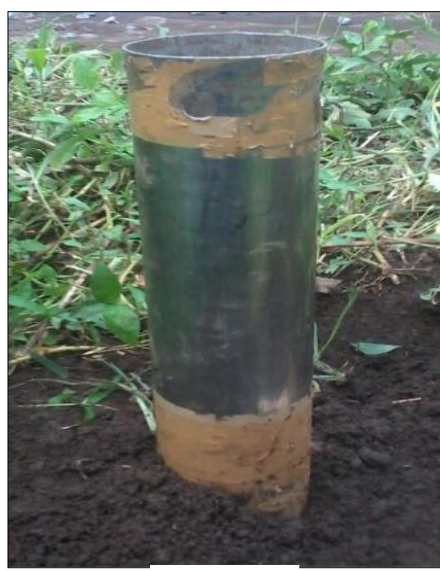

(d)

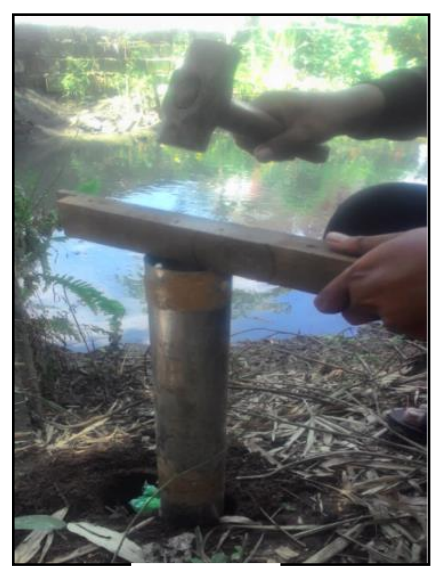

(b)

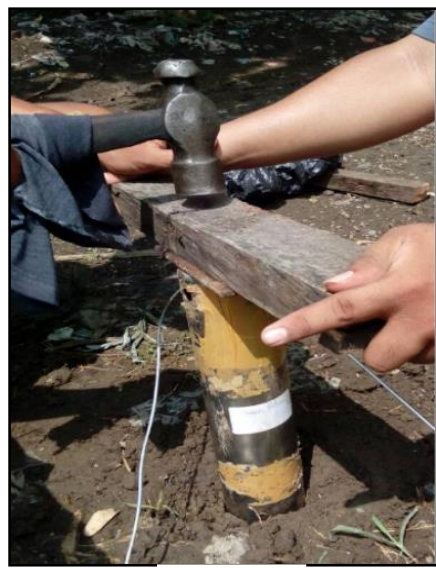

(e)

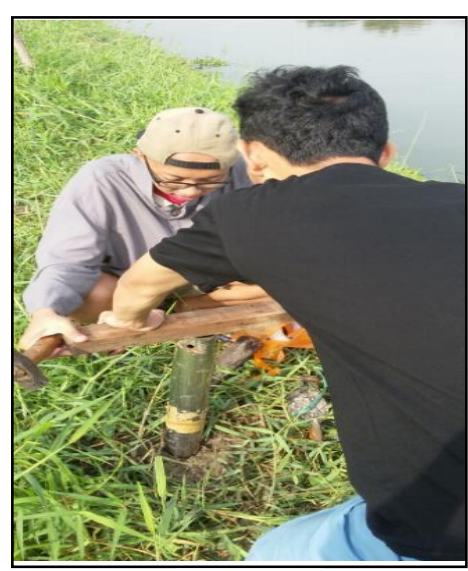

(c)

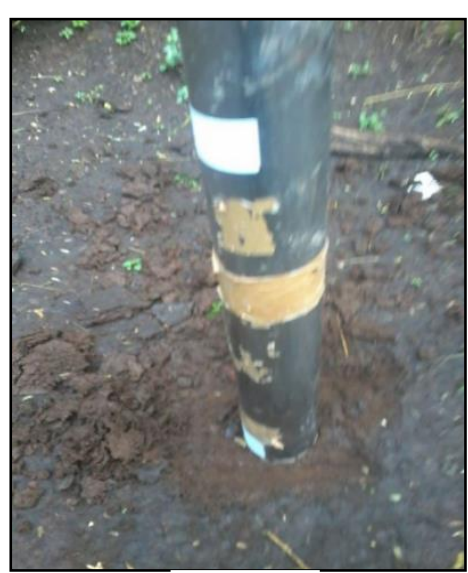

(f)

Figure1.Soil sampling in (a) Surabaya, (b) Sidoarjo, (c) Lumajang, (d) Mojokerto, (e) Bangkalan, (f) Gresik.

As presented in Figure 1, the sampling sites were in six areas: Surabaya, Sidoarjo, Lumajang, Mojokerto, Bangkalan and Gresik. The research was carried out in the soil mechanics laboratory of civil and environmental water engineering

\section{Result and discussion}

The value of hydraulic conductivity was obtained from the average conductivity of each pressure that was, $0.008 \mathrm{~kg} / \mathrm{cm} 2,0.026 \mathrm{~kg} / \mathrm{cm} 2 ; 0.054 \mathrm{~kg} / \mathrm{cm} 2 ; 0.108 \mathrm{~kg} / \mathrm{cm} 2 ; 0.206$ $\mathrm{kg} / \mathrm{cm} 2$ and $0.402 \mathrm{~kg} / \mathrm{cm} 2$. Conductivity is the ability of the soil to flow the water which is indicated by Darcy's law. The hydraulic conductivity is affected by the granular exchange and the type of fluid, with the formula as follows. Where $\mathrm{K}$ is the hydraulic conductivity, is the change in the depth of water in the soil against the width of the water range. The results showed that the conductivity of each region at a pressure of $0.008 \mathrm{~kg} / \mathrm{cm} 2$ can be seen in the Table 1 and Figure 2. 
Table 1. Hydraulic conductivity in many soil sample

\begin{tabular}{|c|c|c|c|}
\hline Soil sample & Hydraulic conductivity & Soil type & Source \\
\hline Lumajang & $1,767599 \mathrm{~m} / \mathrm{s}$ & Sand clay loamy & \multirow{6}{*}{$\begin{array}{l}\text { Field Researcher, } \\
2017\end{array}$} \\
\hline Mojokerto & $0,291684 \mathrm{~m} / \mathrm{s}$ & Sand clay loamy & \\
\hline Bangkalan & $0,087 \mathrm{~m} / \mathrm{s}$ & Clay & \\
\hline Sidoarjo & $0,165626(\mathrm{~m} / \mathrm{s}$ & Sand loamy & \\
\hline Gresik & $0,342206 \mathrm{~m} / \mathrm{s}$ & Clay & \\
\hline \multirow[t]{16}{*}{ Surabaya } & $0,177234 \mathrm{~m} / \mathrm{s}$ & Sand loamy & \\
\hline & $1-5 \mathrm{~m} /$ day & Fine sand & \multirow{7}{*}{$\begin{array}{l}\text { Hofkes and Visscher } \\
\text { (1986). }\end{array}$} \\
\hline & $20-100 \mathrm{~m} /$ day & Coarse Sand & \\
\hline & $100-1000 \mathrm{~m} /$ day & Gravel & \\
\hline & $50-100 \mathrm{~m} /$ day & Gravel mix sand & \\
\hline & $0,1-1,0 \mathrm{~m} /$ day & Sand rocky & \\
\hline & $0,01-0,05 \mathrm{~m} /$ day & Clay & \\
\hline & $0-30 \mathrm{~m} /$ day & Rock & \\
\hline & $5,18 \times 10-7 \mathrm{~cm} / \mathrm{s}$ & \multirow{3}{*}{ Clay } & \multirow{3}{*}{$\begin{array}{l}\text { Yoon and Mochtar } \\
\text { (2015) }\end{array}$} \\
\hline & $4,34 \times 10-7 \mathrm{~cm} / \mathrm{s}$ & & \\
\hline & $1,38 \times 10-4 \mathrm{~cm} / \mathrm{s}$ & & \\
\hline & $6 \times 10-3 \mathrm{~cm} / \mathrm{s}$ & \multirow{3}{*}{$\begin{array}{l}\text { Sand } \\
\text { Silt } \\
\text { Clay }\end{array}$} & \multirow{3}{*}{$\begin{array}{l}\text { Bughici and Wallach } \\
\text { (2016) }\end{array}$} \\
\hline & $1,4 \times 10-3 \mathrm{~cm} / \mathrm{s}$ & & \\
\hline & $1,1 \times 10-3 \mathrm{~cm} / \mathrm{s}$ & & \\
\hline & $2,544 \mathrm{~cm} /$ day $-2,617 \mathrm{~cm} /$ day & \multirow{2}{*}{$\begin{array}{l}\text { Sand } \\
\text { Sand loamy }\end{array}$} & \multirow[t]{2}{*}{ Wang et al (2015) } \\
\hline & $2,275 \mathrm{~cm} /$ day $-2,374 \mathrm{~cm} /$ day & & \\
\hline
\end{tabular}

Conductivity hydraulic is related to porosity. Therefore, we can conclude that the soil in Madura has lower conductivity because of the clay or loamy in the soil which lowers the water flow. At sand dan clay, the infiltration rate was $5 \mathrm{~cm} /$ hour and $0,05 \mathrm{~cm} /$ hour respectively (Dalai \& Ramakarjha, 2014). Contaminant transportation depends on the distance and conductivity hydraulic, biological process and physiochemical process (Mustafa et al., 2016; Nham et al ., 2015). The conductivity in each site or region is different (Shwetha \& Varija, 2015). This was the reason for taking 6 soil samples on 6 different sites. Knowing the type of soil in the northern part of East Java is also important since one of the objectives for further research is to determine the local soil type that can decrease TSS and total coli to produce the standardized drinking water. Permeability is the ability of water to flow through the porous media. Soil mechanism has both physical and biological processes (Kedziorek \& Bourg, 2009; Price et al., 2013; Valdes et al, 2014).

Table 1 shows different conductivities that/ were identified from this study. In the lower conductivity, although it produces water with the better quality, the quantity is less. This method was used as the preliminary analysis in the application of infiltration gallery. 
Figure 2 illustrates the infiltration gallery process. Infiltration gallery is a technology used in processing water naturally in the soil. Consisting of perforated pipe covered by gravels, this tool serves as a container and infiltration water filter (Jurel et al., 2013; Jones. 2008). Some mechanisms of water treatment that occur in the soil are adsorption, filtration, degradation and recovery, or purification. The picture shows the gallery (perforated pipe/gallery) which is installed under the river (river bed) with a depth of 6 meters and a length of 50 meters. The water from the river is infiltrated through the soil then collected in a hollow pipe. Water from the pipe gallery enters the pre-filter container which contains sand and finally flows into the fine sand filter as the last stage. This water is then collected to wells. The surrounding communities will pump it every they need it for consumption. According to Kusuma et al. (2018a) and Kusuma et al. (2018b), media filter using soil especially sand loamy could remove TSS and coli.

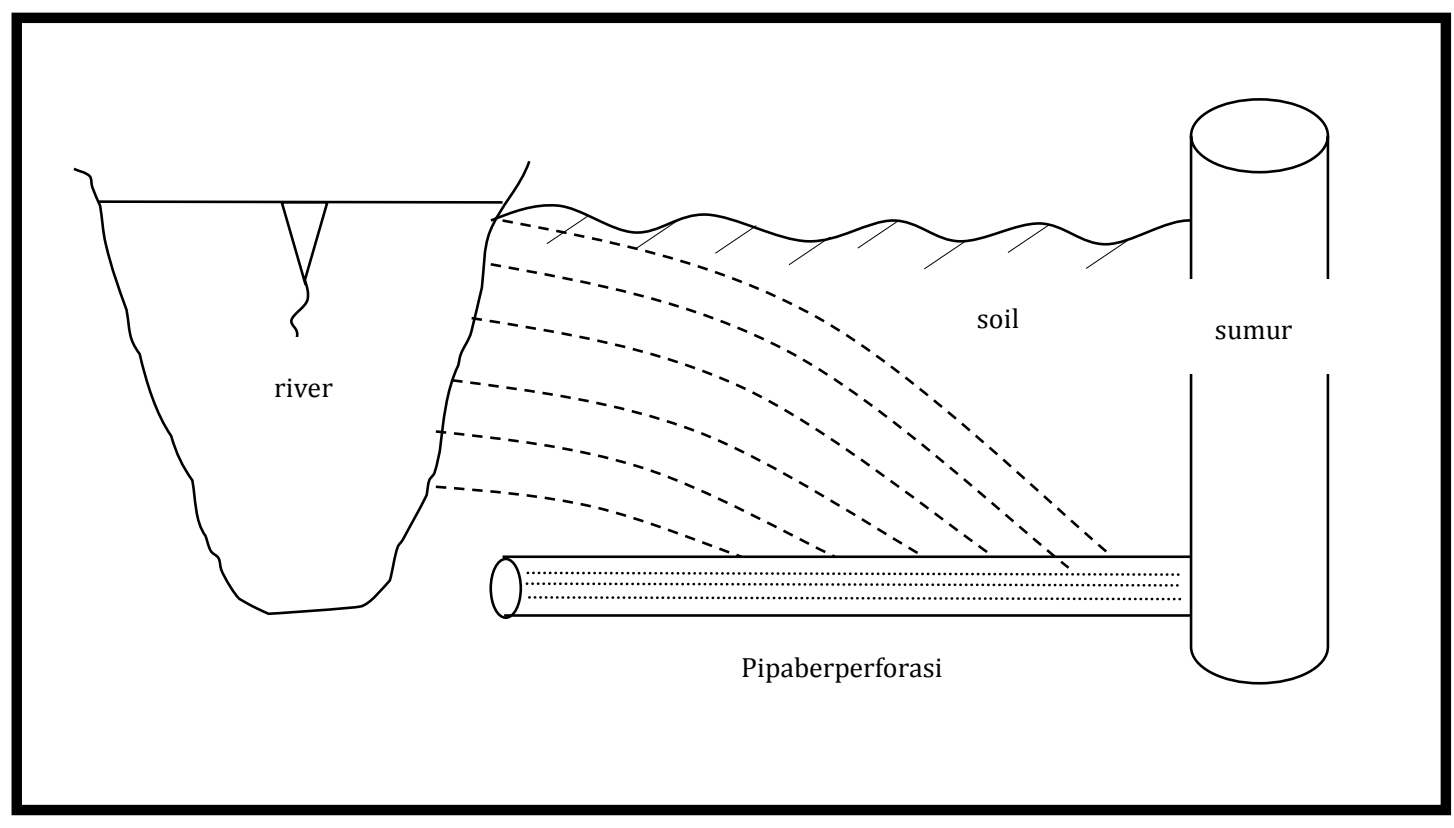

Figure 2. Infiltration gallery

\section{Conclusion}

The researcher found that the same soil types have different conductivities. Therefore, before applicating the infiltration gallery, we have to know the hydraulic conductivity in that site. Infiltration gallery can produce good water quality if the conductivity is lower. Clay in JawaTimur has a hydraulic conductivity of $0.087-0.342206$ (m/s). The sand loamy there,has a hydraulic conductivity of $0.165626-0.177234(\mathrm{~m} / \mathrm{s})$. The transportation of contaminant in the soil highly depends on the soil hydraulic conductivity. In this case, the lower the hydraulic conductivity value is, the better the quality of the water is. 


\section{References}

Asare,E.B. and Bosque-Hamilton, E.K. 2004. The performance of infiltration gallery used a simple water treatment option for small rural community -goviefeagodome in the volta region, Ghana. Water SA. 30: 0378-4738.

Aqualinc. 2014. Infiltration gallery investigation. Marlborough district council.

Barbiero, L., Filho. A.R., Furquim, S.A.C., Furian, S., Sakamoto.A.Y., Valles, V., Graham, R.C., Fort, M., Ferreira.R.P.D. and Neto, J.P.Q. 2008. Soil morphological control on saline and freashwaterlake hydrogeochemical in the pantanal of Nhecolandia, Brazil.Geoderma. $148: 91-106$.

Bekele, E., Toze, S., Patterson, B., Fegg, W., Shackleton, M., and Higginson, S. 2013.Evaluating two infiltration gallery designs for managed aquifer recharge using secondary treated wastewater.Journal of enviromental management. 117:115-120.

Blavier, J., Vernabanck, M.A., Craddock, F., Liegeois, S., Latinis, D., Gargouri, L., Flores Rua, G., Debaste, F., Haut, B., 2014. Investigation of riverbed filtration systems on the Parapetiriver, Bolivia. Journal of Water Process Engineering. 1: 27-36

B.C. Ministry of Environment. 2014. Underground Stormwater Infiltration: Best Practices for the Protection of Groundwater in British Columbia. ISBN 978-0-7726-6855-4

Bughici, T. and Wallach, R. 2016.Formation of soil-water repellency in olive orchards and its influence on infiltration pattern.Geoderma 262:1-11.

Dalai,C. and Ramakarjha. 2014. A preliminary experimental analysis of infiltration capacity through disturbed river bank soil sample. International journal of Engineering and Applications 2248-9622: 24-29

Henzler, A.F., Greskowiak, J., Massmann, G. 2014. Modelling the fate of organic micropollutant during river bank filtration (Berlin, Germany). Journal of contaminat hidrology. 156: 78-92

Hofkes, E.H. andVisscher, J.T. 1986. Artificial soil water recharge for water supply of mediumsize communities in developing countries. International Reference Centre for Community Water Supply and Sanitation. The Hague, TheNethersoils

Hoffman, A. and Gunkel, G. 2011. Bank filtration in the sandy littoral zone of lake (Berlin): Stucture and dynamics of the biological active filter zone and clogging processes. Limnologica. 41:10-19

Hutchinson, A.J., Tokash, J.C. and Logan, B.E. 2011.Analysis of carbon fiber brush loadingin anodes on startup and performance of microbial fuel cells.Journal of Power Sources. 196: 9213-9219

Jekel, M., and Heinzmann, B. 2013. The Research Project "Natural and Artificial Systems for Reacharge and Filtration (NASRI)", its Relation to the Specific Water Management Challenges of Berlin and the International Relevance. KompetenzZentrum Wasser Berlin.Conferece Wasser Berlin.

Jones, A.T. 2008. Can we reposition the preferred geological conditions necessary for an infiltration gallery? The development of a synthetic infiltration gallery. Desalination. 


\section{1:598-601}

Jurel, E.R.S., Bahadur Singh, E.R.B.,Jurel, S.K., and Singh, R.D. 2013. Infiltration Galleries: "A Solution To Drinking Water Supply For Urban Areas Near Rivers". IOSR Journal of Mechanical and Civil Engingeering5: 29-33.

Kedziorek, M.A.M., and Bourg, A.C.M. 2009. ElectronTrapping capacity of dissolved oxygen and nitarte to evaluate $\mathrm{Mn}$ and $\mathrm{Fe}$ reduction dissolution in alluvial aquiversduruing riverbank filtration. Jounal Hidrology. 365 :74-78

Kusuma, M.N., Hadi, W.,Wirjodirdjo, B., and Yulfiah. 2018a. Correlation between quality and quantity from pollutants absorption by soil to the application of infiltration gallery. Poll Res. 37 (2) : 85-89.

Kusuma.M.N., Hadi, W. and Wirjodirdjo, B. 2018b.Preliminary study ofInfiltration Gallery for Water Treatment towards Universal Access 2019 in Indonesia. Soil Environ. 37 (1) : 8388.

Mustafa, S., Bahar, A., Azis, Z.A. and Suratman, S., 2016.Modelling contaminant transport for pumping well. Journal environmental management. 165: 159 -166

Martin, R. and Dillion.P. 2002. Aquifer storage and recovery future directions for south australia. The departement of water, land and biodiversity conservation CSIRO land and water.

Nham, H.T.T., Greskowiak, J., Nodler. K., Rahman, M.A., Spachos, T., Ruterberg, B., Massmann, G., Sauter, M.and Licha, T. 2015.Modeling the transport behaviour of 16 merging organic contaminants during soil quifer treatment. Science of the total environment. 514:450-458.

Price,W.D., Burchell1l, M.R., Hunt, W.F. and Chescheir, G.M. 2013.Long term study of dune infiltration system to treat coastal stromwater runoff for fecal bacteria. Ecological Bactaria $55: 1-11$

Paterson, B.M., Shackleton, M., Furness, A.J., Bekele, E., Pearce, J., Linge, K.L., Busetti,Spadek, T.and Toze, S. 2011.Behaviour and fate nine recycled water trace organics during managed aquifer recharge in an aerobic aquifer. Journal contaminant hidrology. $122: 53-62$

Rummler, J., Bekele, E. andToze, S. 2015. Prelimenary hydrogeological characterisation for proposed covered infiltration galleries at CSIRO Laboratory, Floreat, Western Australia. National book Research Flagship.

Sulam.D.J,and Ku. H.F.H. 1977.Trends of selected ground water constituent from infiltration galleries, southest Nassau Country, New York. Ground water15 : 6.

Shwetha, P. and Varija, Kb. 2015.Soil water retention curve from saturated hydraulic conductivity for sandy loam and loamy sand textured soils. Aquatic Procedia. 4: $142-$ 1149 .

Tagar, A.A., Changying, J., Qishuo., D., Adamowski., J., Malard, J. and Eltouma, F. 2016. Implications of variability in soil structures and physio-mechanical properties of soil after different failure patterns. Geoderma. 261:124-132. 
Valdes, D., Dupont, J.P., Laignel, B., Slimani, S. andDelbart, C. 2014.Infiltration processes in karstic chalk investigated through a spatial analysis of the geochemical properties of the groundwater: The effect of the superficial layer of clay-with-flints. Journal of Hydrology. $519: 23-33$.

Wang, M., Kong, L. and Zang, M. 2015. Effects of sample dimensions and shapes on measuring soil water characteristic curves using pressure plate. Journal of Rock Mechanics and Geotechnical Engineering. 7:463-468.

Yoon, J. and El Mochtar, C.S. 2015.A filtration model for evaluating maximum penetration distance of bentonite grout through granular soils.Computers and Geotechnics. 65:291-301 